STUDIA PRAWNO-EKONOMICZNE, T. CXII, 2019

PL ISSN 0081-6841; e-ISSN 2450-8179 $\quad$ s. 137-154

https://doi.org/10.26485/SPE/2019/112/8

\title{
Tomasz TULEJSKI*
}

iD https://orcid.org/0000-0001-9466-1173

\section{SAMUELA RUTHERFORDA KONCEPCJA GENEZY SPOŁECZEŃSTWA, WŁADZY I PAŃSTWA}

\begin{abstract}
(Streszczenie)
Samuel Rutherford - prominentny szkocki teolog prezbiteriański oraz wpływowy myśliciel polityczny okresu angielskiej wojny domowej - jest autorem interesującej kontraktowej genezy społeczeństwa i państwa. Opierając się na teologicznej konstrukcji przymierza, postrzega je z jednej strony jako realizację zaszczepionego w duszy człowieka prawa natury, z drugiej zaś jako dzieło samych ludzi. W jego perspektywie podstawą legitymacji władzy jest dobrowolna umowa zawarta pomiędzy rządzącymi i rządzonymi. Konsekwencją tego złożenia jest ograniczony charakter władzy oraz podporządkowanie prawu. Autor dowodzi, że ta konstrukcja teoretyczna jest podstawą sformułowanej przez Rutherforda koncepcji tyranii oraz prawa oporu.
\end{abstract}

Słowa kluczowe: Rutherford; rewolucja purytańska; umowa społeczna

\section{Wstęp}

Kulminacyjnym momentem trwającej od czasów panowania Jakuba I wrogości pomiędzy królem i Parlamentem była wojna domowa, która ostatecznie rozstrzygnąć miała o tym, kto w angielskim systemie konstytucyjnym zajmuje rolę dominującą oraz jaką formę instytucjonalną przyjąć ma angielski kościół narodowy. Te dwie kluczowe kwestie były bowiem ze sobą w koncepcjach teoretycznych obu stron konfliktu immanentnie powiązane, obie bowiem łączyło w dużym stopniu podobne uzasadnienie, obie odwoływały się do podobnej genezy i funkcji społecznych asocjacji, pełniących odmienne, lecz komplementarne funkcje. Sama

* Dr hab., prof. UŁ, Uniwersytet Łódzki, Wydział Prawa i Administracji, Katedra Doktryn Polityczno-Prawnych; e-mail: ttulejski@tlen.pl 
wojna domowa rozpoczęła się bowiem od nieudanej próby narzucenia Szkocji przez Karola I angielskich rozwiązań eklezjalnych zgodnie z modelem, który jego ojciec określił krótkim stwierdzeniem No Bishop, no King ${ }^{1}$. Dlatego jeszcze w okresie narastającej wrogości pomiędzy królem a Długim Parlamentem, zanim 22 sierpnia 1642 r. podniesiono w Nottingham królewski sztandar, Parlament, realizując jeden z postulatów Wielkiej Remonstracji, powołał Westminsterskie Zgromadzenie Świętych. Celem tego ciała złożonego z wybranych przez Gminy, Lordów, Londyn i uniwersytety delegatów, z których wielu było uznanymi autorytetami religijnymi i znawcami Biblii, miało być określenie teologicznego kanonu oraz ustroju eklezjalnego Anglii. W obradach uczestniczyło wielu prominentnych przedstawicieli angielskich stronnictw religijnych i politycznych ${ }^{2}$ : od Erastian (Coleman, Selden), poprzez Prezbiterian (Reynolds, Gouge), na Independentach kończąc (Goodwin, Bridge, Burroughs, Nye, Simpson). W Zgromadzeniu uczestniczyli jednak nie tylko Anglicy, bowiem na mocy Uroczystej Ligi i Przymierza pomiędzy Szkocją i Anglią ta ostatnia miała „wykorzenić papizm, episkopat ${ }^{3}$ oraz wszystkie typy herezji” oraz zreformować „religię zgodnie z prawem Boga i przykładem najlepszych zreformowanych kościołów”4. Czyli w zamiarze Szkotów wprowadzić rozwiązania eklezjalne zbliżone do rozwiązań szkockich, choć wydaje się, że Anglicy rozumieli sens Ligi nieco inaczej ${ }^{5}$. Dlatego szkocki Parlament wysłał do Londynu jedenastu komisarzy, którzy mieli uczestniczyć w Zgromadzeniu, reprezentując swój kraj i kościół narodowy. Wśród nich pierwsze skrzypce grało czterech prominentnych teologów: George Gillespie, Robert Baillie, Alexander Henderson oraz Samuel Rutherford, stanowiąc w praktyce o sile całego obozu prezbiteriańskiego ${ }^{6}$. Ten ostatni swej intelektualnej aktywności nie ograniczał jednak jedynie do zagadnień teologicznych i eklezjalnych,

1 James I (VI), Appendix C. James and Puritans, w: The Political Works of James I, Harvard University Press, Cambridge 1918, s. xc.

2 Patrz: W.M. Hetherington, History of the Westminster Assembly of Divines, James Gemmell, Edinburgh 1878, s. 129-139.

3 Interesujące, że sam Kalwin, będący wyrocznią dla wyspiarskich purytanów w swoich listach do Edwarda VI nigdzie nie potępił ani angielskiego episkopalizmu, ani angielskiej liturgii - D. Estrada, Rutherford as a Presbyterian Theologian and Political Thinker, Christianity \& Society October 2003/XIII/4, s. 8 .

4 S.R. Gardiner, The First Two Stuarts and the Puritan Revolution, Charles Scribner's Sons, New York 1895, s. 138.

5 Ch. Hill, The English Bible and the Seventeenth-Century Revolution, Endeavour Press, London 2014, s. 184.

6 R.P. Kerr, The People's History of Presbyterianism in All Ages, The Presbyterian Committee Publication, Richmond 1888, s. 131-132. 
lecz na okres obrad Zgromadzenia datowane jest jego jedyne dzieło poświęcone w całości zagadnieniom stricte politycznym. Dzieło, zaznaczmy już na początku, nietuzinkowe, które przynajmniej dla teorii nowoczesnej umowy społecznej wydaje się nie do przecenienia, choć swą sławą (zapewne przez swój oczywiście chrześcijański i kalwiński charakter ${ }^{7}$ ) znacznie ustępuje Lewiatanowi i Dwóm traktatom o rzadzie $e^{8}$. Więcej nawet, znane jest tylko nielicznym znawcom problematyki, choć na tle ówczesnych argumentów, opierających uprawnienie polityczne na umowie czy kontrakcie jawi się jako niebywale oryginalne i pionierskie. Stanowi bowiem odejście od jej wspólnotowej, a zatem w istocie postśredniowiecznej jeszcze postaci umowy o władzę, wprowadzając wywiedzione z idei covenant wątki indywidualistyczne, których ostateczne konsekwencje znaleźć będzie później można w rozważaniach Hobbesa, levellerów czy Locke'a. Nie pada w nim ani razu sformułowanie umowa społeczna, lecz rozwija ideę covenant prostą drogą prowadzący do nowożytnych pomysłów kontraktualistycznych. Traktat Lex, Rex or The Law and the Prince, bo o nim tu mowa, stanowi równocześnie wykład radykalnej myśli prezbiteriańskiej ${ }^{9}$, różniącej się od ugodowego $\mathrm{w}$ istocie stanowiska jego angielskich kompanionów, reprezentowanych chociażby przez Richarda Baxtera ${ }^{10} \mathrm{i}$ wymierzone jest przede wszystkim w rojalistyczną koncepcję boskiego prawa królów, będąc bezpośrednią odpowiedzią na traktat królewskiego kapelana Johna Maxwella (usuniętego z Kościoła Szkocji) - Sacro-sancta Regum Majestas, or, The Sacred and Royal Prerogative of Christian Kings ${ }^{11}$. Stąd celem niniejszego artykułu jest analiza genezy społeczeństwa, władzy oraz państwa w refleksji politycznej Rutherforda oraz wskazanie jej nowatorskich elementów, opierających się przede wszystkim na wolicjonalnym oraz indywidualistycznym, przynajmniej w wymiarze koncepcyjnym, postrzeganiu początków wszelkich społecznych i politycznych agregacji. Dlatego na początku poddam analizie jego koncepcję początków społeczeństwa, zasadniczo odmienną od wcześniejszych, wywiedzionych z tradycji klasycznej i scholastycznej jego wizji jako bytu danego i naturalnego. Następnie przejdę do Rutherfordowskiej

7 R. Flinn, Samuel Rutherford and Puritan Political Theory, The Journal of Christian Reconstruction 1978-799/5, s. 49.

8 J. Coffey, Politics, Religion and the British Revolutions. The mind of Samuel Rutherford, Cambridge University Press, Cambridge 1997, s. 10.

9 W. Makey, The Church of the Covenant, 1637-1651. Revolution and Social Change in Scotland, John Donald Publishers, Edinburgh 1979, s. 59; G.P. Gooch, English Democratic Ideas in the Seventeenth Century, Harper \& Row, New York, Evanston, London 1959, s. 98.

10 P. Chang-Ha Lim, In Pursuit of Purity, Unity, and Liberty. Richard Baxter's Puritan Ecclesiology in Its Seventeenth-Century Context, Brill, Leiden, Boston 2004, s. 11.

11 R. Flinn, op. cit., s. 50-51. 
teorii władzy politycznej oraz jej legitymacji będącej krytyką idei boskiego prawa królów. Dzięki temu będzie możliwe przedstawienie koncepcji umowy o władzę będącej w istocie dla Rutherforda aktem politycznego powiernictwa.

\section{Geneza społeczeństwa}

Indywidualizm, w ramach którego argumentuje Rutherford, jest w radykalnej kalwińskiej tradycji konsekwencją specyficznie rozumianej idei biblijnego przymierza, którą odnaleźć można już w pierwszym pokoleniu reformatorów (Bullinger, Ursinus, Oleveanus, Zwingli) i która została powszechnie zaakceptowana w reformowanej teologii ${ }^{12}$. Na Wyspach zaś tak istotnego znaczenia nabrała po przekładzie Biblii Tyndale'a z 1532 r., w którym hebrajski termin brit i grecki diatheke przetłumaczono z premedytacją jako covenant ${ }^{13}$. Przymierze z Bogiem stało się dla protestantów wygodnym, zainspirowanym Starym Testamentem ${ }^{14}$, narzędziem zakwestionowania politycznego, religijnego oraz społecznego status quo jako historyczna i etyczna podstawa każdego społeczeństwa, rządu i porządku prawnego. Zwłaszcza w Szkocji idea covenant trafiła na podatny grunt, gdzie od dawna istniała tradycja kontraktów pomiędzy klanami i ich grupami. Związki, pakty i przysięgi zawierane były tu dla celów wspólnej obrony i polubownego załatwiania sporów. Zatem nietrudno było te tradycje połączyć ze zreformowanym pojęciem przymierza, szczególnie w kontekście obrony ich wersji kalwinizmu przed ingerencją południowego sąsiada. W konsekwencji w Szkocji powstał pomysł, by konstrukcję tę wykorzystać dla uzasadnienia prawowitości i celów relacji publicznych ${ }^{15}$, zwłaszcza za sprawą Knoxa, który w swej The History of the Reformation in Scotland rozwija pomysły Zwingliego i Bullingera ${ }^{16}$ i nadaje idei covenant polityczny wymiar ${ }^{17}$. Kalwińską ideę przymierza pomiędzy Bogiem

12 D. Visser, Covenant, w: H.J. Hillerbrand (red.), The Oxford Encyclopedia of the Reformation, Vol. I., Oxford University Press, Oxford 1996, s. 442-445.

13 D.J. Elazar, Covenant and Commonwealth. From Christian Separation through the Protestant Reformation. The Covenant Tradition in Politics, Vol. II, Transaction Publisher, New Brunswick 1998, s. 231.

14 H. Silving, The jurisprudence of the Old Testament, New York University Law Review 1953/28, s. 1130-1131.

15 D.J. Elazar, Covenant and Commonwealth, s. 271.

16 A.W.G. Raath, S.A. de Freitas, Calling and resistance: Huldrych Zwingli's (1484-1531) political theology and his legacy of resistance to tyranny, Koers 2002/66 (1), s. 71.

17 R.L. Greaves, John Knox and the Covenant Tradition, Journal of Ecclesiastical History 1973/ XXIV/1, s. 26-29. 
a człowiekiem przeniósł na płaszczyznę polityczną, pisząc o przymierzu pomiędzy Bogiem a wiernymi ${ }^{18}$. W ten sposób przymierze zawarte między Adamem i później Abrahamem a Bogiem stało się w kalwińskiej teologii rodzajem specjalnej konstytucji danej przez Stwórcę rodzajowi ludzkiemu, a przestrzeganie boskich praw było w niej gwarancją boskiego błogosławieństwa. Purytanie dokonali zatem przetłumaczenia języka biblijnego na język polityki, chcąc zaaplikować starotestamentowe prawdy do porządku społecznego. Przymierze jest moralnie uzasadnioną umową lub paktem bazującym na dobrowolnej zgodzie ustanowionej poprzez przysięgę lub przyrzeczenie pomiędzy ludźmi lub ich agregacjami na zasadzie niezależności i równości stron. Zawarte jest ono pod określonymi warunkami, dla określonych celów i respektowane przez wszystkie strony. Zatem do samej istoty przymierza należy zgoda i obietnica ${ }^{19}$. Dlatego wszystkie relacje społeczne - między Bogiem i człowiekiem, pastorami i zgromadzeniem, sędziami i członkami ich społeczności, między członkami rodzin zostały przedefiniowane w kategoriach umowy lub przymierza, które polega na zgodzie i wzajemnej odpowiedzialności ${ }^{20}$. Dobrowolność i będący jej istotą woluntaryzm prowadziły równocześnie do wniosku, iż społeczeństwo, organizacja kościelna i relacje pomiędzy władzą a poddanymi oparte powinny być na tych samych zasadach ${ }^{21}$. W tej optyce są one prostym przedłużeniem przymierza zawartego pomiędzy Bogiem i ludźmi przekształcającego ich w chrześcijańską wspólnotę.

W tym duchu właśnie argumentuje Rutherford, łącząc swą wizje społeczeństwa $\mathrm{z}$ własną koncepcją prawa natury, którym są reguły pierwotnie wyryte w sercu Adama i choć zniekształcone przez grzech pierworodny, to ciągle obecne w pewnym stopniu w duszy każdego człowieka ${ }^{22}$. Istnienie społeczeństwa jest bowiem dla niego częścią Bożego planu w tym sensie, że jednostki dążą

18 W. Stanford Reid, John Knox's Theology of Political Government, Sixteenth Century Journal 1988/XIX/4, s. 531.

19 D.J. Elazar, Covenant and Polity in Biblical Israel. Biblical Foundations and Jewish Expressions. The Covenant Tradition in Politics, Vol. I, Transaction Publishers, New Brunswick, New Jersey, London 1995, s. 22-23.

20 P. Miller, Errand into the Wilderness, Harvard University Press, Cambridge 1956, s. 48-49.

21 J.W. Gough, The Social Contract. A Critical Study of its Development, Clarendon Press, Oxford 1975 , s. 84 .

22 S. Rutherford, Lex, Rex, or The Law and the Prince; A dispute for The Just Prerogative of King and People: containing The reasons and causes of the most necessary defensive wars of the Kingdom of Scotland, and of their Expedition for the aid and help of their dear brethren of England; in which their innocency is asserted, and a full answer is given to a seditious pamphlet, entitled, Sacro-Sancta Regnum Majestatis, Robert Ogle and Oliver \& Boyd, Edinburgh 1843 , I, s. 1. 
do realizacji tej tkwiącej $\mathrm{w}$ ich naturze tendencji jako elementu prawa naturalnego. Źródłem tych skłonności nie jest więc Boski rozkaz, lecz naturalne skłonności zaszczepione w ludzkiej naturze w samym akcie stworzenia. Jego źródłem jest więc naturalny rozum, który Rutherford nazywa osadem Boga ${ }^{23}$. Prawo natury jest zatem rozumem wiodącym ludzi ku społeczeństwu politycznemu. Choć idea ta jest częścią porządku natury ${ }^{24}$, to jej realizacja ma miejsce już w porządku łaski/konwencji i w tym sensie fundamentalnie różni się od rodziny, do której przynależność nie jest zasadniczo kwestią wyboru czy decyzji, lecz instynktu. O ile więc idea społeczeństwa zaszczepiona jest w ludzkiej duszy od czasów Kreacji, to samo powstanie społeczeństwa musi mieć charakter dobrowolnej agregacji, choć realizującej przyrodzoną człowiekowi tendencję. Podąża zatem Rutherford ścieżką wytyczoną przez Buchanana, który był przekonany, że ludzie na początku nie posiadali żadnych praw, lecz znajdowali się w prymitywnej kondycji, a społeczeństwo powołali nie w wyniku rozważenia jego ewentualnych korzyści, lecz realizując naturalny instynkt. Był on u niego synonimem prawa natury danego im przez Boga, by wiedzieć co uczynić, by odróżnić dobro od zła i obronić swe życie ${ }^{25}$. „Człowiek rodzi się z natury wolny - pisze zatem Rutherford - od wszelkiego poddaństwa z wyjątkiem tego, które jest najmilsze i najbardziej naturalne, czyli podporządkowania ojcowskiego lub synowskiego, albo podporządkowania żony mężowi, szczególnie zaś wolny jest od naturalnego podporządkowania księciu ${ }^{26}$. Ponieważ - przekonuje dalej Rutherford - społeczeństwo domowe jest naturalnym przykładem, jak społeczeństwo obywatelskie jest naturalne in radice w swych korzeniach, lecz dobrowolne in modo, w sposób koalescencyjny. Zakładając więc - pisze dalej - że ludzie łączą się w społeczeństwo, lub że społeczeństwo nie zawiera się w rodzinie, wtedy naturalne jest, że ludzie przyłączają się do społeczeństwa obywatelskiego, choć sposób zjednoczenia w ciele politycznym, jak mówi Bodin, jest dobrowolny" ${ }^{27}$. Uderza zatem coś, co nieobecne było we wcześniejszych katolickich i protestanckich koncepcjach genezy społeczeństwa, czyli jego dobro-

\section{Ibidem, I, s. 5.}

24 Podobnie jak prawo własności, o którym pisze: „Jest moralnie niemożliwe, by nie było rozróżnienia na meum et tuum, moje i twoje; i dziesięć przykazań Bożych zabraniających kradzieży i pożądania żony innego mężczyzny [...] jest dowodem, że podział rzeczy jest częścią (choć ludzie są obecnie w stanie grzechu) prawa natury tak dalece, iż jest oczywistą podstawą prawa narodów" - ibidem, XVI, s. 67-68.

25 G. Buchanan, De jure regni apud Scotos, or, A dialogue, concerning the due priviledge of government in the kingdom of Scotland, Richard Baldwin, London 1689, s. 8-11.

27 Ibidem, I, s. 1-2. 
wolny i woluntarystyczny charakter. Dla myślicieli takich jak choćby Hooker czy Baxter, osadzonych jeszcze w arystotelejskiej i scholastycznej tradycji, było ono bytem naturalnym. To ono, jako całość, było podmiotem ewentualnej zgody czy kontraktu o władzę, podmiotem obowiązków i uprawnień wyprzedzającym konkretne indywidua, które przez nie były definiowane. U Rutherforda przyjmuje tymczasem, przynajmniej na poziomie koncepcyjnym, formę dobrowolnej organizacji wolnych i równych (o czym niżej) jednostek jednoczących się dla wspólnego celu, istniejącego już wcześniej w ich świadomości.

\section{Władza i geneza państwa}

U Rutherforda, który używał takiego języka podczas obrad w Westminsterze, ów kontraktualny woluntaryzm obejmuje nie tylko powstanie samego społeczeństwa. Idea covenant wpływa też u niego bezpośrednio na powstanie rządu oraz jego charakter. Pierwszy jednak problem, jaki podnosi Rutherford w swej analizie, problem, który ostatecznie determinuje jego wszystkie dalsze rozważania, to kwestia samej genezy władzy. Dlatego powołuje się na argumenty z Listu do Rzymian $\left(13 ; 1-4{ }^{28}\right)$, wedle którego sama idea władzy pochodzić musi od Boga. „Cała władza polityczna - pisze więc - wywodzi się bezpośrednio z Boskich korzeni, ponieważ: 1. Bóg uczynił człowieka istotą społeczną i ten, kto pragnie być rządzony przez człowieka z pewnością musiał umieścić tę moc w ludzkiej naturze $\mathrm{z}$ dobrego powodu, jak naucza Arystoteles. 2. Bóg i natura mają na celu politykę i pokój ludzkości, stąd Bóg i natura dały ludzkości moc, by zmierzyła się z tym celem, i musi nią być władza rządu" ${ }^{29}$. Stąd z samej społecznej natury człowieka, powołanej do życia przez Stwórcę, determinującej konieczność wspólnego bytowania wynika potrzeba istnienia władzy mogącej zapewnić wspólnocie przetrwanie i pokój. Jak w całej niemal tradycji reformowanej dla Rutherforda państwo jest więc ustanowionym przez Boga porządkiem narzuconym na upadłego człowieka jako remedium na jego grzech. Relacje społeczne, z racji zdeprawowanej ludzkiej natury, nie są bowiem pokojowe i bezkonfliktowe. „Jeśli - pisze Rutherford - wszyscy byliby bezgrzeszni nie czyniliby innym gwałtu, prawo mogłoby rządzić wszystkimi i wszyscy ludzie mogliby je egzekwować, agendo sponte, przez czynienie do-

28 W Biblii Króla Jakuba fragment ten brzmi następująco: „Let every soul be subject unto the higher powers. For there is no power but of God: the powers that be are ordained of God" (The Holy Bible, Baker, London 1611, strona nienumerowana - wydanie pierwsze).

29 S. Rutherford, Lex, Rex..., I, 1. 
bra z własnej woli, to nie potrzebowaliby króla, który zmuszałby ich do tego. Ale ponieważ ludzie z natury sprzeciwiają się dobrym prawom, dlatego istnieje potrzeba władcy"30. By społeczeństwo mogło funkcjonować, musi istnieć w nim siła zdolna okiełznać indywidualne rządze domkniętych grzechem ludzi i zjednoczyć ich wysiłki w jednym kierunku. Dlatego Bóg, najwyższy Pan i Król całego świata namaszcza urzędników, by będąc Mu podlegli, sprawowali władzę nad ludem dla Jego chwały i dobra wspólnego: „Królewskie imperium jest zasadniczo po to, by nakarmić, kierować, obronić oraz rządzić w pokoju i pobożności (1 TM. II.2) jak czyni to ojciec swych dzieci”31. „Chrystus - pisze gdzie indziej - używa chrześcijańskich urzędników jako swe sługi, by przegonić wilki od swej trzody" 32 . Wyposażył ich więc w prawo miecza dla obrony społeczeństwa i zachęty dla ludzi, by podążali ścieżką cnoty i dobra. Król jest zatem publicznym sługą, który chroni społeczeństwo, i wykonawcą woli Boga dla dobra, bezpieczeństwa, pokoju i zbawienia ludzi. Społeczeństwo bez władzy jest zatem społeczeństwem niepełnym, które zniszczyć może samo siebie. Lecz choć człowiek jest z natury grzeszny, to możliwe jest powołanie do życia porządku politycznego, który powstrzyma lub złagodzi ową grzeszną naturę. Wymaga ona według Rutherforda politycznej i prawnej interwencji, by skłonić ją do porządku i dyscypliny. Rząd jest konieczny, by powstrzymać zło oraz zachować pokój w społeczeństwie i Bóg musiał zaszczepić świadomość środków osiągniecia tych celów w ludzkiej naturze ${ }^{33}$. Wbrew władzy grzechu, rozum umocniony przez łaskę jest w stanie dostrzec naturalne prawo, którym powinien się kierować. Dlatego oświecone prawem natury zjednoczone w społeczeństwie jednostki dojść muszą do konkluzji, że konieczne jest istnienie władzy wyposażonej w prawo miecza.

Stąd drugim fundamentalnym problemem nurtującym Rutherforda jest określenie genezy władzy w jej personalno-konkretnym wymiarze. Wszystko oczywiście zmierza do uzasadnienia jej kontraktowej genezy, dlatego ostrze jego argumentacji skierowane jest, co w tych okolicznościach oczywiste, przeciwko

\footnotetext{
Ibidem, XXII, s. 101.

Ibidem, XVI, s. 64.
}

32 S. Rutherford, A free disputation against pretended liberty of conscience tending to resolve doubts moved by Mr. John Goodwin, John Baptist, Dr. Jer. Taylor, the Belgick Arminians, Socinians, and other authors contending for lawlesse liberty, or licentious toleration of sects and heresies, Andrew Crook, London 1649, s. 192.

33 W.M. Campbell, Lex, Rex and its Author, Scottish Church History Society 1941, s. 216. 
obozowi rojalistycznemu. Stara się więc dezawuować argumentację rojalistów opierającą się na wywiedzionym jeszcze od Saravii, Jakuba I, De Dominisa czy Barclaya boskim prawie królów, wedle którego monarchowie posiadają przyrodzone boskie prawo panowania, które implikuje bezwzględne posłuszeństwo poddanych wobec ich woli ${ }^{34}$. W przeciwieństwie do kontynentalnych teoretyków koncepcji Wyspiarze odnosili je jednak nie do urzędu królewskiego jako takiego, lecz do samej osoby władcy ${ }^{35}$. W tej argumentacji władza pochodzi od Boga nie tylko jako konieczna społeczeństwu idea, która może przyjąć rozmaite formy realizacji, lecz także, a może przede wszystkim, w wymiarze personalno-konkretnym, czyniąc z władcy Bożego pomazańca, co doskonale oddał Jakub I (VI) Stuart, mówiąc: „W Piśmie Królowie nazywani są Bogami, poprzez porównanie ich władzy z władzą Boską, gdyż mogą oni stwarzać i niszczyć swych poddanych, mają władzę wywyższania i poniżania, prawo życia i śmierci, sądzenia we wszystkich przypadkach swych poddanych, nie odpowia-

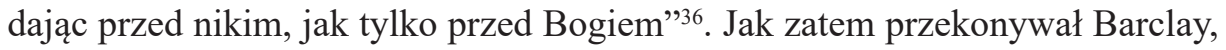
królowie stoją ponad wszystkimi ludźmi i prawami pozytywnymi, odpowiadając jedynie przed Bogiem, a nie przed żadną ziemską instancją ${ }^{37}$. Istnieje więc naturalny, niezależny od woli ludzi autorytet polityczny wywodzący swą władzę wprost od Stwórcy. Władca jest więc co prawda człowiekiem, lecz także małym Bogiem, którego ustanowił Stwórca, by „panował nad innymi ludźmi”"38. „Królowie - podkreśla Jakub - są nazywani bogami przez prorokującego króla Dawida, ponieważ zasiadają za zezwoleniem Boga na Jego ziemskim Tronie i mają udział w rządzeniu, dany im ze względu na Niego" "39. Jak dowodził zaś Maxwell „Pismo Święte wskazuje nam, że wszyscy Królowie, wszystkie Suwerenne władze pochodzą bezpośrednio od Boga" ${ }^{40}$. Uprawnienie do korony wynika z prawa dziedziczenia, które jest nienaruszalne, a następstwo określone

34 Co interesujące, sama koncepcja boskiego prawa królów była odpowiedzią na kontynentalne i szkockie idee, jak pierwszy nazwał ich Barclay, monarchomachów - Q. Skinner, The Foundations of Modern Political Thought, Volume Two: The Age of Reformation, Cambridge University Press, New York 1978, s. 300-301.

35 W.F. Church, Constitutional Thought in Sixteenth-Century France. A Study in the Evolution of Ideas, Harvard University Press, Cambridge 1941, s. 249.

36 Speech of 1609-1610, w: The Political Works of James I, s. 307-308.

37 J.N. Figgis, The Divine Right of Kings, Cambridge University Press, Cambridge 1914, s. 5-6.

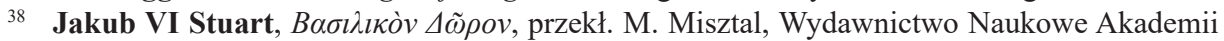
Pedagogicznej, Kraków 2006, s. 65.

39 James VI (I), The Trew Law of Free Monarchies, w: The Political Works of James I, s. 54.

40 J. Maxwell, Sacro-sancta Regum Majestas, or, The Sacred and Royal Prerogative of Christian Kings, Thomas Dring, London 1680, s. 41. 
jest wedle zasady primogenitury. Tak nabyte prawo nie może zostać utracone przez żaden czyn uzurpacji, niezależnie jak długo ona trwa ani przez usunięcie z tronu. Choć więc istnieje możliwość, że władca stanie się tyranem, to obowiązkiem poddanych jest posłuszeństwo i żarliwa modlitwa. Monarchia jest zatem czystą suwerennością niemożliwą do formalnego ograniczenia. Nawet król nie może jej ograniczyć, dzielić z kimkolwiek, a jakakolwiek taka próba jest zaprzeczeniem jej istoty, bowiem summa imperium spoczywa w rękach Bożego pomazańca. Król tylko posiada wyłączność w dziedzinie tworzenia prawa, skupia w swym ręku władzę pełną i nieograniczoną, a wszystkie przywileje poddanych czy kompetencje innych organów państwa mają źródło w jego łasce $^{41}$. „Doktryna - twierdzi Maxwell - że Królowie pochodzą wprost od Boga i są niezależni od wszystkich innych stworzeń uczy także, że jest wielką rebelią przeciwko Bogu sprzeciwianie się lub opór wobec króla". Jakikolwiek bunt czy nieposłuszeństwo są więc grzechem przeciwko Bogu i drogą ku potępieniu. Dlatego „nasze posłuszeństwo wobec Królów nie jest przypadkowe, warunkowe lub kontraktowe, lecz konieczne i narzucone przez Boga" ${ }^{2}$. Społeczeństwa ludzkie zaś, jako naturalne agregacje zgodnie z prawem natury, jak dowodzi De Dominis, muszą być rządzone, nie mają zaś prawa rządzić43 ${ }^{4}$ W tej optyce władza króla pochodzi więc wprost od Boga, a źródłem jej może być tak podbój (jak chce Saravia ${ }^{44}$ ), bezpośrednie Boskie namaszczenie (jak w przypadku Saula czy Dawida) czy przede wszystkim urodzenie. Figgis w swym fundamentalnym studium problemu cytuje adres Uniwersytetu w Cambridge do Karola II z roku 1681 będący kwintesencją tej koncepcji. „Nadal wierzymy i utrzymujemy - czytamy w nim - że nasi Królowie nie wyprowadzają swego tytułu od ludu, lecz od Boga, wobec którego tylko są odpowiedzialni; że nie należy do poddanych tworzyć ich czy krytykować, lecz szanować i dawać posłuch ich władcy, który stał się nim poprzez dziedziczne prawo następstwa, którego żadna religia, żadne prawo, żaden błąd lub strata nie mogą zmienić ani pomniejszyć" 45 .

Tymczasem dla Rutherforda usprawiedliwione może być jednak tylko znane ze Starego Testamentu bezpośrednie wyznaczenie monarchy przez Boga. Przestało jednak mieć ono jakiekolwiek znaczenie dla określenia prawomoc-

${ }^{41}$ B. Szlachta, Monarchia prawa? Angielska myśl polityczna doby Tudorów, Księgarnia Akademicka, Kraków 2007, s. 663.

42 J. Maxwell, op. cit., s. 299.

43 J.P. Sommerville, Royalists and Patriots. Politics and Ideology in England 1603-1640, Routledge, London, New York 2014, s. 26-27.

44 Ibidem, s. 28.

45 J.N. Figgis, op. cit., s. 6. 
ności władcy od czasu, gdy Bóg nie mówi już przez proroków i nie ustanawia władców nad swym ludem. Podbój zaś jest niczym więcej, jak „królewską grabieżą”, a panowanie nad ,zdobytym królestwo niczym więcej jak continuata injuria, grabieżą nieustanną"46. ,Jeśli akt podboju - pisze gdzie indziej Rutherford - jest gwałtowny i niesprawiedliwy, nie jest manifestacją regulującej i akceptującej woli Boga i nie może być dowodem tytułu do korony”47. „Nie wolno sądzić - przekonuje dalej - że jest to boski tytuł do korony, ponieważ nie ma on w sobie nic z istoty króla, lecz jest gwałtownym i krwawym nabyciem, które w swym nasileniu bliskie jest uciskowi Nimroda, najokrutniejszej tyranii, która nie ma w sobie nic z tego, co konstytuuje króla; nie ma bowiem nic z bohaterskiej i królewskiej mądrości i szczodrobliwości, nic z akceptującej i regulującej Boskiej woli, która musi być zamanifestowana każdemu, kto ma być królem"48. Skoro tak, to poddanych nie wiąże ze zdobywcą żaden obowiązek posłuszeństwa, bo choć czasem sam Bóg ustanawia w ten sposób króla, to dzieje się to za sprawą jego nieprzeniknionej dla człowieka mądrości i woli, który bezpośrednio podlega ujawnionym wprost w Piśmie Bożym regułom, a te oczywiście, wedle Rutherforda, odmawiają legitymacji krwawym zdobywcom przyrównywanym przez niego, jak wyżej, do Nimroda - starotestamentowego archetypu tyrana.

Podobnie jak podbój nie może być więc źródłem legitymacji panującego, tak samo nie przekonuje autora Lex, Rex wywodzenie jej z faktu samego urodzenia. Jego zdaniem bowiem wszyscy ludzie rodzą się równi w swej władzy i jurysdykcji, stąd nikt nie posiada żadnej przyrodzonej politycznej władzy nad innymi. „Nie istnieje żadne prawo natury - czytamy więc - które narzucałoby zwierzchność nad istotami żyjącymi, bo nie bez powodu w naturze nie ma panowania dzika nad dzikiem, lwa nad lwem, smoka nad smokiem, byka nad bykiem, a więc jeśli wszyscy ludzie rodzą się wolni, jak mam nadzieję udowodnić, to nie ma $\mathrm{z}$ natury powodu, dla którego jeden człowiek powinien być królem i panem nad innymi, dlatego wszelka jurysdykcja człowieka nad człowiekiem jest sztuczna i wynika z prawa pozytywnego"49. Każdy z natury jest wolnym człowiekiem (freeman born) i nikt w łonie matki nie jest przeznaczony, by być królem lub być mu podporządkowanym. Linia sukcesji nie jest naturalna, lecz przypadkowa, a nawet zgoda ludu dana ojcu nie rozciąga się automatycznie na syna i dalszych potomków. Przymioty, które uczyniły z woli poddanych kogoś

\footnotetext{
S. Rutherford, Lex, Rex..., IV, s. 8-9.

Ibidem, XII, s. 46.

8 Ibidem, XII, s. 47.

49 Ibidem, II, s. 2.
} 
królem, wcale nie muszą legitymować także jego zstępnych, cnota i mądrość nie przynależą do rodziny, lecz do konkretnej osoby. Poza tym dziedziczenie korony, zdaniem Rutherforda, było zatem w oczach Boga jedynie wyjątkiem, a nie regułą, o czym świadczy chociażby przykład Saula i Dawida.

Zatem ostatecznie ani podbój, ani urodzenie, ani bezpośrednie namaszczenie przez Boga, choć z różnych powodów, nie mogą być tytułem do dzierżenia władzy królewskiej. Wobec tego, że żaden argument rojalistów w świetle Pisma i doświadczenia ostać się nie może, to źródeł władzy królów szukać można jedynie w zgodzie czy wyborze rządzonych. I właśnie udowodnieniu tej tezy poświęcony jest w dużej mierze wywód z Lex, Rex.

\section{Umowa o władzę}

Ludzie jako indywidua nie posiadają jednak władzy politycznej, nabywają ją dopiero wtedy, gdy jednoczą się we wspólnocie. Władza ta polega na zdolności wyznaczenia sobie władców i podporządkowania się prawu. Podobnie więc jak u Buchanana ${ }^{50}$, gdy ludzie gromadzą się razem, w naturalny i oczywisty sposób pojawia się więc konieczność jej istnienia jako konieczna konsekwencja pragnienia samozachowania, zaszczepiona w ludzkiej duszy przez Boga. Jest to dla Rutherforda wtórne prawo natury wywiedzione z pierwszorzędnego prawa nakazującego zachować życie. Zaszczepione ono zostało każdemu stworzeniu w akcie Kreacji i do niego zredukowane być mogą wszystkie nakazy prawa natury. Ten naturalny, przyrodzony instynkt kieruje ludzi ku władzy, powodując, że ,przekazujemy naszą władzę w ręce jednego lub większej liczby władców"51. Prawo osobistej samoobrony przysługuje więc na mocy prawa natury jako konsekwencja władztwa nad samym sobą i instynktu samozachowawczego, prawo do obrony przez władzę wynika z prawa pozytywnego opartego na drugorzędnym prawie natury i jest efektem ludzkiej konwencji. Odkąd więc Bóg zaszczepił w ludzkiej duszy pragnienie przetrwania, ustanowił konieczność istnienia urzędników, którzy będą o nie zabiegać, ograniczając jednak równocześnie analogiczne prawo jednostki. Jeśli jednak uważnie przyjrzeć się argumentowi Rutherforda i nie rzutując na nie późniejszych, zdesakralizowanych koncepcji kontraktu, to ludzie nie narzucili na siebie ograniczenia swej władzy samoobrony jako środka ustanowienia rządu, lecz zaakceptowali je jako konsekwencja ich kondycji ustanowionej przez Boga. „Indywidualne osoby - dowodzi - powołując władzę nie zrzekają

${ }^{5}$ G. Buchanan, op. cit., s. 12.

51 S. Rutherford, Lex, Rex..., II, s. 2. 
się swych uprawnień, lecz zrzekają się swej władzy zadania gwałtu innym członkom wspólnoty. Zatem nie będą mieć moralnego prawa czynienia krzywdy bez kary; i to nie jest uprawnienie czy wolność, lecz służebność, ponieważ władza stosowania przemocy i czynienia krzywdy nie jest wolnością, lecz służebnością i poddaństwem" 52 . Dlatego ludzie muszą z konieczności ich wyznaczyć i poddać się ich władzy, by móc realizować jedyną wolność, jaką Rutherford ma na myśli, czyli możliwość moralnego życia w chrześcijańskim państwie. Rządzący są bowiem danym przez Boga remedium na przemoc i niesprawiedliwość będące skutkiem grzesznej ludzkiej natury - ,żywym, racjonalnym, oddychającym prawem zwanym królem, sędzią, ojcem" ${ }^{\text {"53. }}$.

Prawo natury wyznacza więc konieczność realizowalną przez akt woli człowieka. Jako dobry kalwinista uzasadnienia szukać musi oczywiście w Piśmie Świętym, mającym nieoceniona moc perswazyjną. Dlatego odwołując się do Deuteronomium 17: 14,15, wskazuje, że pomimo tego, iż król Izraela musiał zostać wskazany przez Boga, to ostatecznie jego wyniesienia dokonywali ludzie. Skoro bowiem ludzie nie posiadaliby takiej władzy, to Bóg nie mógłby nakazać im dokonania tego, ograniczając się jedynie do wskazania władcy. Co więcej, nawet gdy Bóg uświęcił linię dawidową, to każdoczesny władca, mimo że posiadł władzę na mocy dziedziczenia, nie mógł władać bez przyzwolenia ludu. Władza wynoszenia królów jest więc immanentnie przypisana ludowi, którego zgoda każdocześnie legitymizuje króla. „Władza ta - pisze - jest radykalnie naturalna, tak samo jak pszczoły (jak sądzą niektórzy) mają moc wyboru swej królowej, tak wspólnota ma naturalną władzę bronić się i ochraniać; i Bóg objawił w Deut. XVII. 14, 15 sposób wyboru naczelników i królów, który jest specjalnym środkiem obrony i ochrony; a lud jest głównym źródłem i fontanną władzy królewskiej”"54. Pamiętać należy jednak, że ich wybór kierowany jest przez Boga, zatem, co bardzo dla Rutherforda istotne „nie możemy mówić tutaj o dwóch aktach, jednym Boga, drugim ludzi, ale o jednym i tym samym działaniu; Bóg poprzez wolny wybór i głos ludzi czyni takiego człowieka Królem, pomijając tysiące innych" 55 . W ten sposób władza pochodzi bezpośrednio od Boga i bezpośrednio od ludzi, zatem „Bóg tylko przez działanie ludzi, jako jego narzędzia, może uczynić królem; Bóg tylko poprzez działanie ludzi, jako jego narzędzia, może zdetronizować króla" ${ }^{56}$. Odwołując się do De legibus

\footnotetext{
Ibidem, VII, s. 25-26.

Ibidem, XXIV, s. 116.

Ibidem, XL, s. 203.

Ibidem, IV, s. 7.

Ibidem, XL, s. 202.
} 
Suareza dowodzi też, że Bóg jest bezpośrednim autorem władzy politycznej w tym znaczeniu, że stworzył ludzi, którzy z natury muszą posiadać władzę, by móc funkcjonować we wspólnocie. Była ona naturalna także w tym znaczeniu, że ludzie przenosili władzę polityczną całej wspólnoty, która jest elementem porządku natury, na rządzących, by realizowali jej naturalne funkcje ${ }^{57}$. „Bóg - zatem - daje władzę królewską poruszając serca ludzi, by przyznali władzę królewską, która jest faktycznie w ludziach, formalnie zaś od Boga"58. Choć więc władza królewska została wymyślona przez Boga, nie przez ludzi, to w rezultacie powołana została w poszczególnych państwach za sprawą ich woli. Co prawda, więc za istnieniem poszczególnych rządów stoi Bóg, lecz ludzie zostali aktywnie włączeni w proces ich tworzenia.

Władza rządzących ma przy tym charakter umowy zawartej na określonych warunkach, ,jest to oczywiste zobowiązanie Króla wobec ludu w akcie koronacji i ludu wobec króla, jak w umowach pomiędzy panem i wynajętym sługą, czy między dwoma kupcami" ${ }^{59}$. Racjonalny namysł realizuje więc przyrodzoną naturalną konieczność, lecz w sposób przez naturę niezdeterminowany, dlatego „Bóg wyznaczył króla lub naczelnika, który troszczył będzie się o tę wspólnotę, będzie rządzić nią w pokoju i ochroni wszystkich przed wzajemnymi aktami przemocy" ${ }^{60}$. Bez króla istnienie sprawiedliwego społeczeństwa jest fizycznie niemożliwe, bez niego anarchia i gwałt wezmą górę, dlatego jego ustanowienie jest obowiązkiem zaszczepionym w umyśle przez światło natury. Rutherford ujmuje to następująco: „Po pierwsze wyznaczenie przez rzeczpospolitą władców, by rządzili nie jest czynem obojętnym, lecz moralnym, ponieważ ich nieustanowienie jest, jak myślę, naruszeniem piątego przykazania. Po drugie, w zakresie wolnej woli ludzi nie ma wyboru pomiędzy istnieniem a nieistnieniem rządu, ponieważ nie należy do wolnej woli posłuszeństwo lub nieposłuszeństwo wobec sądu natury, który jest sądem Boga, a sąd ten stwierdza, że społeczeństwa cierpią a ludzkość ginie, gdy nie wyznaczy się żadnego rządu" ${ }^{\text {". }}$. Do jego powołania dochodzi więc wskutek horyzontalnie rozumianego przymierza, gdzie równe sobie, umawiające się strony dokonują powołania państwa, jedna strona kon-

57 J.D. Ford, Lex, rex iusto posita: Samuel Rutherford on the origins of government, w: R.A. Mason (red.), Scots and Britons Scottish political thought and the union of 1603, Cambridge University Press, Cambridge, New York, Melbourne, Madrid, Cape Town, Singapore, Sao Paulo 1994, s. 268.

S. Rutherford, Lex, Rex..., V, s. 11.

S. Rutherford, A free disputation..., s. 218-219.

S. Rutherford, Lex, Rex..., XVII, s. 69

${ }^{61}$ Ibidem, III, s. 5. 
traktu staje się władcą, pozostałe jej poddanymi. Dochodzi do wzajemnego zobowiązania (mutual covenant), zgodnie z którym król rządzi zgodnie z prawem, a ludzie są zobowiązani do posłuszeństwa władzy, a obie strony uprawnione są do zmuszenia drugiej strony do przestrzegania warunków umowy. Kontrakt ten nie może zostać w normalnych warunkach anulowany, chyba że na mocy zgodnej woli obu stron. Zatem król nie stoi ponad przymierzem i ponad prawem, które uczyniły go królem. Królowie, którzy są rozumnymi ojcami i przewodnikami swego ludu, którzy władają zgodnie z prawem, dbają o pokój wewnętrzny i bezpieczeństwo, wyprowadzają swą władzę z kontraktu i przymierza z ludem, stając się strażnikami wszystkich dobrych praw. Symbolicznym zaś aktem zawarcia przymierza i poddania prawu jest koronacja oraz przysięga koronacyjna.

\section{Rekapitulacja}

Ta argumentacja służy ostatecznie Rutherfordowi do wykazania słuszności argumentu będącego fundamentem całego antykrólewskiego obozu w przededniu oraz w trakcie Rewolty Purytańskiej - podlegania monarchy prawu oraz interesom wspólnoty politycznej. W optyce tej władca jest jedynie jej częścią i sługą stojącym na straży jej bezpieczeństwa, dobrobytu i pomyślności. Dalszą konsekwencją zaś koncepcja tyranii oraz uzasadnienie prawa oporu. Dla Rutherforda wydaje się absurdem, by Bóg uświęcić mógł władzę absolutną. Jest też nieracjonalne, by ludzie wbrew nakazom prawa natury zrzekli się nieodwołalnie wolności własnej i wolności swych dzieci, która nie należy przecież do nich, i ustanowili nad sobą nieograniczonego prawem króla, redukując się sami do niewolników. Cel państwa, jakim jest bezpieczeństwo poddanych, także wskazuje oczywiście, że trudno jest go zrealizować w warunkach władzy absolutnej. Dzieje się tak z uwagi na upadły charakter ludzkiej natury, bowiem posiadanie nadmiernej władzy musi ostatecznie prowadzić do degeneracji i jej wystąpieniu przeciwko dobru wspólnemu ${ }^{62}$. „Społeczeństwo polityczne - dowodzi więc - tak jak wynika to z naturalnego instynktu, że może wyznaczyć swą głowę lub głowy, tak samo, jeżeli ich głowa lub głowy staną się żarłocznymi wilkami, choć Bóg natury nie zostawił mu doskonałego remedium, to może zarówno opierać się im, jak i ukarać głowę lub głowy, którym dali całą swą władzę dla swego dobra, a nie dla zniszczenia"63. Choć Bóg nakazuje posłuszeństwo wobec władzy, to władza nadużyta przestaje mieć Boskie źródło,

62 Ibidem, XIV, s. 54-62.

63 Ibidem, XXVI, s. 129. 
a władcy przestają być Bożymi sługami, gdyż nie działają dla dobra swego ludu. Władza jest błogosławieństwem danym przez Boga ludowi, by „bronić ubogich i potrzebujących, by zachować obie tablice Prawa i aby utrzymywać ludzi w ich wolności od ucisku i nastawania jednych na drugich" ${ }^{64}$. Nie może być więc przekleństwem wiążącym się z niewolnictwem, zagrożeniem ich życia i bezpieczeństwa. Dlatego władza, „która jest przeciwna prawu, która jest zła i tyraniczna nie może wiązać się z żadnym podporządkowaniem [...], a jeśli nie wiąże się z podporządkowaniem, można się jej legalnie opierać” ${ }^{65}$. „Król jest po to - pisze w zakończeniu Lex, Rex, - by kierować, monarchia, by rozkazywać zamkom, fortom, portom, twierdzom, broni, magazynom, milicji zatrudnionym do obrony królestwa. Wszystkie drogi, mosty i trakty publiczne należą do króla, o ile jako publiczny i królewski strażnik broni poddanych przed złoczyńcami, mordercami sam, i przez niższych urzędników, lecz nie może użyć tych zasobów przeciwko królestwu" ${ }^{6}$.

\section{Bibliografia}

Buchanan George, De jure regni apud Scotos, or, A dialogue, concerning the due priviledge of government in the kingdom of Scotland, Richard Baldwin, London 1689.

Campbell William M., Lex, Rex and its Author, Scottish Church History Society 1941, s. 204-228.

Chang-Ha Lim Paul, In Pursuit of Purity, Unity, and Liberty. Richard Baxter's Puritan Ecclesiology in Its Seventeenth-Century Context, Brill, Leiden, Boston 2004.

Church William F., Constitutional Thought in Sixteenth-Century France. A Study in the Evolution of Ideas, Harvard University Press, Cambridge 1941.

Coffey John, Politics, Religion and the British Revolutions. The mind of Samuel Rutherford, Cambridge University Press, Cambridge 1997.

Elazar Daniel J., Covenant and Commonwealth. From Christian Separation through the Protestant Reformation. The Covenant Tradition in Politics, Vol. II, Transaction Publisher, New Brunswick 1998.

Elazar Daniel J., Covenant and Polity in Biblical Israel. Biblical Foundations and Jewish Expressions. The Covenant Tradition in Politics, Vol. I, Transaction Publishers, New Brunswick, New Jersey, London 1995.

Estrada David, Rutherford as a Presbyterian Theologian and Political Thinker, Christianity \& Society, October 2003/XIII/4, s. 4-11.

Figgis John N., The Divine Right of Kings, Cambridge University Press, Cambridge 1914.

Flinn Richard, Samuel Rutherford and Puritan Political Theory, The Journal of Christian Reconstruction 1978-799/5, s. 49-74.

${ }^{64}$ Ibidem, XXVIII, s. 141.

65 Ibidem.

66 Ibidem, XLIV, s. 234. 
Ford John D., Lex, rex iusto posita: Samuel Rutherford on the origins of government, w: Roger A. Mason (red.), Scots and Britons Scottish political thought and the union of 1603, Cambridge University Press, Cambridge, New York, Melbourne, Madrid, Cape Town, Singapore, Sao Paulo 1994.

Gardiner Samuel R., The First Two Stuarts and the Puritan Revolution, Charles Scribner's Sons, New York 1895.

Gooch George P., English Democratic Ideas in the Seventeenth Century, Harper \& Row, New York, Evanston, London 1959.

Gough John W., The Social Contract. A Critical Study of its Development, Clarendon Press, Oxford 1975.

Greaves Richard L., John Knox and the Covenant Tradition, Journal of Ecclesiastical History 1973/XXIV/1, s. 23-32.

Hetherington William M., History of the Westminster Assembly of Divines, James Gemmell, Edinburgh 1878.

Hill Christopher, The English Bible and the Seventeenth-Century Revolution, Endeavour Press, London 2014.

Hillerbrand Hans J. (red.), The Oxford Encyclopedia of the Reformation, Vol. I., Oxford University Press, Oxford 1996.

The Holy Bible, Baker, London 1611.

Kerr Robert P., The People's History of Presbyterianism in All Ages, The Presbyterian Committee Publication, Richmond 1888.

Makey Walter, The Church of the Covenant, 1637-1651. Revolution and Social Change in Scotland, John Donald Publishers, Edinburgh 1979.

Mason Roger A. (red.), Scots and Britons Scottish political thought and the union of 1603, Cambridge University Press, Cambridge, New York, Melbourne, Madrid, Cape Town, Singapore, Sao Paulo 1994.

Maxwell John, Sacro-sancta Regum Majestas, or, The Sacred and Royal Prerogative of Christian Kings, Thomas Dring, London 1680.

Miller Perry, Errand into the Wilderness, Harvard University Press, Cambridge 1956.

The Political Works of James I, Harvard University Press, Cambridge 1918.

Raath Andries W.G., de Freitas Simon, Calling and resistance: Huldrych Zwingli's (1484-1531) political theology and his legacy of resistance to tyranny, Koers 2002/66 (1), s. 45-76.

Rutherford Samuel, $A$ free disputation against pretended liberty of conscience tending to resolve doubts moved by Mr. John Goodwin, John Baptist, Dr. Jer. Taylor, the Belgick Arminians, Socinians, and other authors contending for lawlesse liberty, or licentious toleration of sects and heresies, Andrew Crook, London 1649.

Rutherford Samuel, Lex, Rex, or The Law and the Prince; A dispute for The Just Prerogative of King and People: containing The reasons and causes of the most necessary defensive wars of the Kingdom of Scotland, and of their Expedition for the aid and help of their dear brethren of England; in which their innocency is asserted, and a full answer is given to a seditious pamphlet, entitled, Sacro-Sancta Regnum Majestatis, Robert Ogle and Oliver \& Boyd, Edinburgh 1843.

Silving Helen, The jurisprudence of the Old Testament, New York University Law Review 1953/28, s. 1129-1148. 
Skinner Quentin, The Foundations of Modern Political Thought, Volume Two: The Age of Reformation, Cambridge University Press, New York 1978,

Sommerville J.P., Royalists and Patriots. Politics and Ideology in England 1603-1640, Routledge, London, New York 2014.

Stanford Reid W., John Knox's Theology of Political Government, Sixteenth Century Journal 1988/XIX/4, s. 529-540.

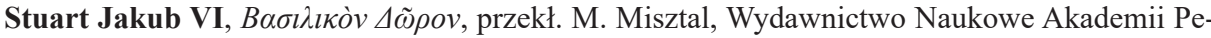
dagogicznej, Kraków 2006.

Szlachta Bogdan, Monarchia prawa? Angielska myśl polityczna doby Tudorów, Księgarnia Akademicka, Kraków 2007.

Visser Derk, Covenant, w: Hans J. Hillerbrand (red.), The Oxford Encyclopedia of the Reformation, Vol. I., Oxford University Press, Oxford 1996, s. 442-445.

Tomasz TULEJSKI

\section{SAMUEL RUTHERFORD'S CONCEPT ON GENESIS OF SOCIETY, POWER AND STATE}

( Sum mary)

Samuel Rutherford - a prominent Scottish Presbyterian theologian and influential political thinker of the period of the English Civil War - is the author of the interesting contractual genesis of society and the state. Based on the theological construction of the covenant, he perceives it as the implementation of the laws of nature grafted in the human soul, and on the other hand as the work of the people themselves. In its perspective, the basis for the legitimacy of authority is a voluntary agreement concluded between the rulers and the ruled. The consequence of this submission is the limited character of power and subordination to law. The author argues that this theoretical construction is the basis of the concept of tyranny and the right of resistance formulated by Rutherford.

Keywords: Rutherford; Puritan Revolution; social contract 